\title{
Characteristics of the Florida Nursery Industry: 2003-04 National Nursery Survey Results ${ }^{1}$
}

Alan W. Hodges, and John J. Haydu²

\section{Acknowledgments}

The National Nursery Survey was conducted on behalf of the Green Industry Research Consortium (S-1021 Multi-state Research Committee), formerly known as S-103 and S-290, a group of agricultural economists and horticulturists from 24 U.S.

land-grant institutions. The survey was coordinated by John Brooker and Charles Hall at the University of Tennessee, who assembled nursery lists, and coded and entered data from returned questionnaires. The research was supported in part by a grant from USDA-Forest Service, National Urban and Community Forestry Advisory Committee, together with assistance from the Horticulture Research Institute and American Nursery Association.

\section{Summary}

The value of nursery and greenhouse crops produced in Florida has grown over the last 10 years at a compound annual rate of 2.5 percent in constant dollar terms, reaching \$1.63 billion in 2004 .

Information on the Florida nursery industry in 2003 was generated by the Fourth National Nursery Survey conducted in early 2004. These results are presented for employment, firm size distribution, product sales, growing media types, market channels, marketing methods, irrigation and pest management practices, trade flows, advertising expenses, and use of technology. A total of 476 firms responded to the survey, representing a response rate of 17 percent. The average number of employees per firm was 18.7 persons, with 76 percent as fulltime employees and 24 percent as temporary. About 2 percent of firms also had operations in other states. Sales in 2003 reported by survey respondents totaled an estimated $\$ 603$ million. Some 44 percent of firms had sales of less than $\$ 250,000$, while 29 percent of firms had at least $\$ 1$ million in sales. About 8 percent of firms had $\$ 10$ million or more in sales, which accounted for 38 percent of total sales reported. Plant types that constituted the largest volume of sales were flowering potted plants (13\%), tropical foliage (11\%), vines and ground covers (8\%), annual bedding plants (8\%), propagation materials (7\%), and "other" miscellaneous unspecified plants $(16 \%)$. Native plants accounted for 15 percent of total sales. Container production was the predominant growing system, accounting for 74 percent of sales. Within the wholesale market, the largest channels were

1. This is EDIS document FE628, a publication of the Food and Resource Economics Department, Florida Cooperative Extension Service, Institute of Food and Agricultural Sciences, University of Florida, Gainesville, FL. Published March 2006. Please visit the EDIS website at http://edis.ifas.ufl.edu.

2. Alan W. Hodges, Associate-In, Food and Resource Economics Department, and John J. Haydu, Professor, Food and Resource Economics Department, Mid-Florida Research and Education Center, Apopka, FL, Florida Cooperative Extension Service, Institute of Food and Agricultural Sciences, University of Florida, Gainesville, FL

The Institute of Food and Agricultural Sciences (IFAS) is an Equal Opportunity Institution authorized to provide research, educational information and other services only to individuals and institutions that function with non-discrimination with respect to race, creed, color, religion, age, disability, sex, sexual orientation, marital status, national origin, political opinions or affiliations. U.S. Department of Agriculture, Cooperative Extension Service, University of Florida, IFAS, Florida A. \& M. University Cooperative Extension Program, and Boards of County Commissioners Cooperating. Larry Arrington, Dean 
re-wholesalers and landscape firms, representing 31 percent and 24 percent of sales, respectively, while retail garden centers, retail mass merchandisers, and home improvement centers each represented about 10 percent. Plant brokerage for other growers was reported by 47 percent of growers, and represented nearly 17 percent of total sales. Advance contracting of production was engaged in by 45 percent of firms, but accounted for less than 1 percent of sales. Sales to repeat customers represented 74 percent of total sales. The predominant sales methods used were telephone and personal (in-person) sales, which accounted for 52 and 34 percent of sales, respectively. Published price discounts to large volume customers were offered by 20 percent of firms. Trade shows were the most common type of advertising, accounting for 51 percent of such expenses. Sales to customers within Florida accounted for 71 percent of total sales, while sales to the neighboring states of Georgia and Alabama represented 10 percent of total sales. Exporting to foreign countries was done by 17 percent of firms, and represented 5 percent of sales, with the top export destinations being Canada, Holland, and the Caribbean Basin countries. The most common method of nursery irrigation was overhead sprinklers, used by 76 percent of respondents, followed by drip irrigation (48\%), and the predominant source of irrigation water was groundwater wells, supplying 77 percent of water used. The most commonly reported integrated pest management (IPM) practices used were removing infested plants or plant parts (87\%), cultivation and hand weeding (81\%), and spot treatment with pesticides instead of broadcast spraying (76\%). Computers were most commonly used for the business management functions of word processing (62\%), accounting and cost analysis (58\%), and communications/email (57\%). The most important factors identified for price determination were cost of production, grade of plants, and market demand, while important factors affecting general business and business expansion were market demand, weather uncertainty, competition, production, and personnel.

\section{Introduction}

According to official USDA estimates, the value of nursery and greenhouse crops in Florida was around \$1.63 billion in 2004 (Jerardo, 2005). Florida is the second largest state, behind California, in nursery and greenhouse sales. Since 1995, this value has grown at a compound annual rate of 2.5 percent in constant 2004 dollars (Figure 1). Total value has remained steady since 2001 in nominal dollar terms, but declined in inflation-adjusted terms (GDP Implicit Price Deflator, U.S. Commerce Department). Floriculture crops, including foliage, flowering potted plants, bedding plants, and cut flowers/foliage, were valued at $\$ 826$ million, while other nursery crops, such as landscape woody ornamentals and miscellaneous greenhouse crops, were valued at $\$ 803$ million. The nursery crops grew rapidly during the 1995-97 period, but the trend has been flat since that time.

The economic impacts of the environmental horticulture industry in Florida were assessed in two previous studies (Hodges and Haydu, 1999, 2002). The nursery and greenhouse segment of the industry in Florida had total impacts in 2000 of $\$ 3.48$ billion in output or revenue, $\$ 2.52$ billion in value added or net income, and employment of 54,288 jobs.

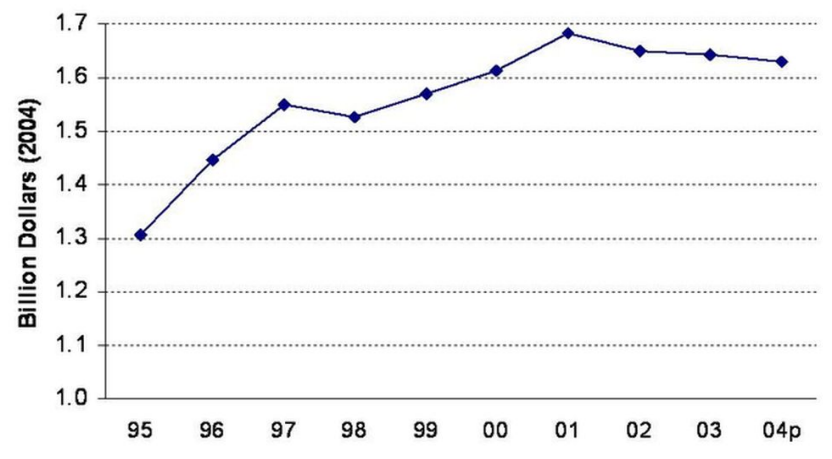

Figure 1. Value of Florida nursery and greenhouse crops, 1995-2004.

\section{Survey Methods}

The National Nursery Survey has been conducted four times at five-year intervals: 1988, 1993, 1998, and 2003. Mailed surveys collected information on selected production and marketing practices, such as distribution channels, interstate and international shipments, advertising expenditures, selling methods, and other information, to help fill the void of publicly available information on management characteristics of the nursery and greenhouse industry, and to provide information useful to growers, allied industry 
professionals, Extension personnel, and researchers. Results of this and previous National Nursery Surveys were reported for all states by Brooker and Turner (1990) and Brooker et al. (1995, 2000, 2005), and previous results for Florida were reported by Hodges and Haydu (2000).

For the first time, the National Nursery Survey in 2003-4 was conducted using a standard sampling methodology, with a total of 44 states participating, including Florida, giving unprecedented coverage for the survey. Questions on the survey have evolved over time, reflecting changes in the industry.

Questions about market channels have been revised to capture sales to mass merchandise chain stores, home centers, multiple-location garden centers, and re-wholesalers. Several new questions were added to the latest survey, to address water use and sources of irrigation water, sales of native plants, and integrated pest management (IPM) practices.

The list of nurseries surveyed in Florida was obtained from the Florida Department of Agriculture-Division of Plant Industry, the agency responsible for licensing nursery producers and enforcing phytosanitary regulations. All producers of plants in the state are legally required to be licensed, so this list is exhaustive. The list contained over 7,700 registered firms, which were stratified in four sized classes based on number of units in plant inventory: large $(100,000+)$, medium $(10,000$ to $99,999)$, small $(1,000$ to 9,999$)$, and very small (less than 1,000). Firms in the very small class were excluded from the survey, since many of these are not bona fide commercial enterprises, leaving a total of 4,498 firms eligible for the survey. From this, a sample of 2,854 firms was selected to survey, including 100 percent of the large firms, and a random selection of 60 percent of the medium- and small-sized firms.

Two complete mailings of the survey were conducted in January and March of 2004. Selected firms were initially contacted by a letter from the investigators to explain the purpose of the survey and encourage their cooperation. Questionnaires were mailed to selected firms, along with postage-paid return envelopes. Reminder postcards were also mailed to respondents about one week after the survey mailings. Respondents were identified by a code number printed on the questionnaire. A copy of the survey questionnaire is presented in the Appendix.

A total of 476 usable questionnaires were returned from Florida growers, including 151 large firms, 148 medium firms, 171 small firms, and 6 firms of undetermined size. This represented an overall response rate 16.7 percent, with response rates somewhat higher (26\%) for large firms (Table 1). A small number of selected questionnaires were returned as undeliverable. The survey data were coded and entered into worksheets for analysis. Annual sales for each firm were estimated at the midpoint or average of the sales range indicated, unless actual sales were specified (Table 2). Sales for each product type, market channel, and region were estimated from the annual sales, together with the percentage breakdown reported by each firm.

\section{Results}

\section{Sales Distribution}

Estimated sales in 2003 reported by Florida survey respondents totaled $\$ 603$ million as shown in Table 3. Overall sales per firm averaged $\$ 1.34$ million. The largest share of firms (44\%) was in the smallest sales size class of less than $\$ 250,000$; however, this group accounted for only 1.5 percent of total sales reported. Firms with at least $\$ 1$ million in sales represented 24 percent of respondents and accounted for 88 percent of total sales reported. About 5 percent of respondents declined to provide sales information.

\section{Employment}

Survey respondents reported a total of 8,030 employees in 2003, of which 76 percent were full-time and 24 percent were temporary, including part-time and seasonal employees (Table 4). The average number of employees per firm was 18.7 persons. Some 43 percent of respondents reported hiring temporary employees. Over half $(57 \%)$ of the firms indicated that their employment had remained the same over the past 5 years, while 29 percent reported that it had increased, and 15 percent said it had decreased. Total sales per employee averaged $\$ 75,112$. 


\section{Nursery Products}

Information on sales reported by survey respondents for various types of nursery products is summarized in Table 5. The largest share of respondents reported selling deciduous shade and flowering trees $(31 \%)$, tropical foliage $(27 \%)$, broad-leaved evergreen shrubs (25\%), evergreen trees $(24 \%)$, and potted flowering plants $(20 \%)$. Other unspecified types of ornamental plants were reported by 26 percent of respondents, which was the largest product group in terms of sales volume, representing 16 percent of total sales reported. The next largest product categories in terms of sales were flowering potted plants $(13 \%)$, foliage $(11 \%)$, vines and ground covers (8\%), annual bedding plants (8\%), and propagation materials (7\%). Lesser products accounting for 3 to 6 percent of total sales were broad-leaved evergreen shrubs, evergreen trees, deciduous shade and flowering trees, edible bedding plants, and fruit trees. Minor products specified included deciduous shrubs, narrow-leaved evergreen shrubs, azaleas, roses, herbaceous perennials, and Christmas trees. Plant categories whose share of total sales increased significantly from the previous survey in 1998 were bedding plants (vegetables, fruits, and herbs), flowering potted plants, fruit trees, and other unspecified plants.

Respondents were also asked to indicate the overall share of their products that were native plants, defined as plants present in North America prior to European settlement. Sales of native plants were reported by 59 percent of respondents, and accounted for 15 percent of total sales.

Growing systems or media types used by Florida nurseries are summarized in Table 6 . Container production was the predominant system used by 84 percent of Florida nurseries, accounting for 74 percent of sales reported. Although this was decreased slightly from previous surveys (80\%), container growing remains the standard in Florida nurseries because of the convenience for handling and marketing, high product quality, and low risk of freeze damage. Balled and burlapped production accounted for 10 percent sales, while bare-root production accounted for 3 percent, and other unspecified media/production systems for 9 percent of sales. Balled/potted, field grow bag, and pot-in-pot systems all accounted for less than 3 percent of sales.

\section{Market Channels and Marketing Practices}

Market channels used by Florida nurseries are summarized in Table 7. Some 87 percent of respondents marketed products through wholesale channels, accounting for 91 percent of sales reported, while 38 percent marketed through retail channels, representing 9 percent of sales. Within the wholesale market, the largest channels were re-wholesalers and landscape firms, which were used by 64 percent and 57 percent of firms, and accounted for 31 percent and 24 percent of sales, respectively. Other important wholesale channels were retail garden centers, retail mass merchandisers, and home improvement centers, each representing about 10 percent of sales reported. Retail chain garden centers accounted for only 4 percent of sales. The share of sales to retail mass merchandisers and home improvement centers has declined slightly from the previous survey. However, they retain a large sales volume, in spite of a relatively small number of growers, indicating that these are very concentrated market channels, held mostly by large producers.

Respondents were asked about brokerage for other growers and contract production. Plant brokerage (i.e., buying and reselling finished plants) was reported by 47 percent of growers, and this activity represented nearly 17 percent of total sales. Production contracted with a buyer in advance was also a common activity engaged in by 45 percent of firms, but represented less than 1 percent of sales, which is significantly lower than reported in previous surveys. Sales were negotiated with customers as to price and terms by 67 percent of respondents, accounting for 34 percent of total sales. Published volume discounts were offered to preferred customers by 20 percent of firms. Sales to repeat customers represented about 74 percent of total sales.

Sales methods used by Florida nurseries are summarized in Table 8. The most commonly used method was in-person sales, used by 84 percent of respondents, which accounted for 34 percent of sales volume; however, telephone sales accounted for a higher share of sales (52\%) although they were used by a slightly lower share of respondents $(73 \%)$. Trade 
shows were also commonly used (21\%), but accounted for a small share of sales (4\%). Mail order and internet sales were used by 7 and 13 percent of respondents, and accounted for 2 percent and 1 percent of sales, respectively.

Survey respondents reported expenses for various forms of advertising, as shown in Table 9. The most common type of advertising was trade shows, reported as used by 25 percent of respondents, and accounting for over half $(51 \%)$ of total expenses. Growers exhibited at an average of 0.8 trade shows annually. Other important advertising methods were trade journals $(15 \%)$, gardening publications $(5 \%)$, and catalogs $(5 \%)$. Other unspecified types of advertising were reported by 15 percent of respondents, and accounted for 7 percent of expenditures. Web sites were used by 18 percent of respondents, but represented only 3 percent of expenses.

\section{Market Areas}

Survey respondents were asked to indicate the share of their total sales to markets within their home state (Florida) and to the top five other states or countries. Sales to customers within Florida accounted for 71 percent of total sales reported; therefore 29 percent of sales were to out-of-state markets (Table 10). The neighboring states of Georgia and Alabama represented 10 percent of total sales reported. The large populated states of Texas and California each represented over 2 percent of total sales. Other states receiving at least 1 percent of sales were North and Carolina, New York, and Michigan. Approximately 78 percent of plants purchased for growing (liners) were from within Florida.

Exporting to foreign countries was done by 17 percent of respondents, and represented 5 percent of sales, which was increased from previous surveys. The top export markets were Canada, Holland, and the Caribbean Basin countries (Table 11). Some sales were also reported to Spain, Belgium, Germany, Australia, and Central and South America.

\section{Production and Management Practices}

Irrigation methods and water sources used by Florida nurseries are summarized in Table 12. The predominant source of water for irrigation was wells, accounting for an average of 77 percent of water used, followed by natural surface water (14\%), municipal (5\%), and recaptured water (3\%). The most common method of irrigation was overhead sprinklers, used by 76 percent of respondents, followed by drip irrigation (48\%), subirrigation or ebb-flood (5\%), and other unspecified types (10\%).

Integrated pest management (IPM) has become an established approach to pest management in the nursery and greenhouse industry. Use of IPM practices was assessed for the first time in the 2003 National Nursery Survey. Use of various practices by Florida growers is summarized in Figure 2. The most commonly used practices, reported by at least half of respondents, were removing infested plants or plant parts $(87 \%)$, cultivation and hand weeding $(81 \%)$, spot treatment with pesticides instead of broadcast spraying (76\%), inspecting incoming stock for insects/diseases (73\%), alternating pesticides to avoid pesticide resistance (72\%), elevating plants for air circulation (66\%), managing irrigation to reduce pests $(53 \%)$ and adjusting fertilization rates to control weed/pest growth $(53 \%)$.

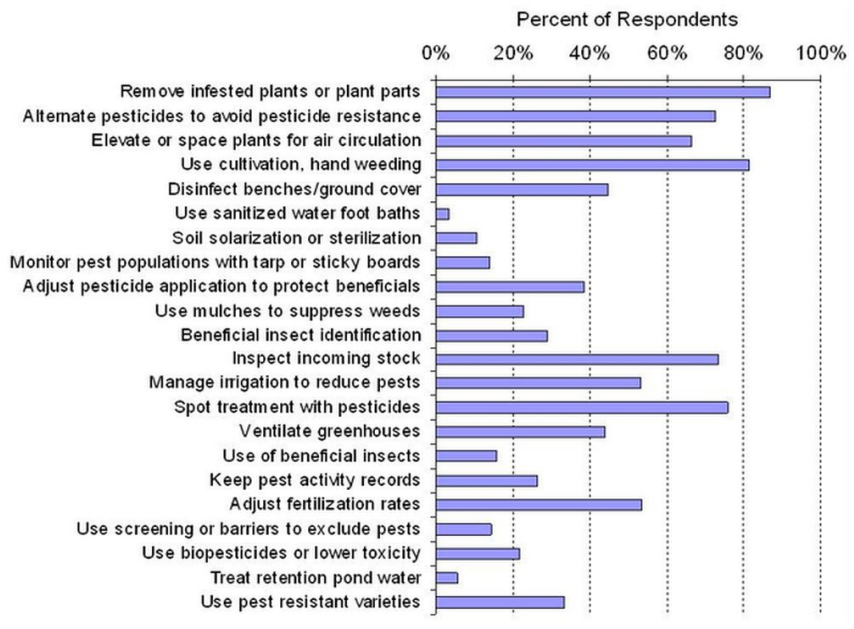

Figure 2. Integrated pest management (IPM) practices used by Florida nurseries, 2003.

Use of computers has become widespread in the nursery and greenhouse industry. Use of computers for various production and management functions reported by Florida survey respondents is shown in 
Figure 3. For each function, respondents were asked to indicate whether they currently use, plan to use, or do not use computers. The functions for which computers were currently used by at least half of respondents were word processing (62\%), accounting and cost analysis (58\%), and communications/email $(57 \%)$. In addition, computerized inventory management was used by 37 percent currently, and 11 percent plan to do so, and internet commerce was reportedly used by 27 percent, with 7 percent expecting to use in the future. Computerized production scheduling was used by only 16 percent, but an additional 9 percent expect to adopt these applications in the future.

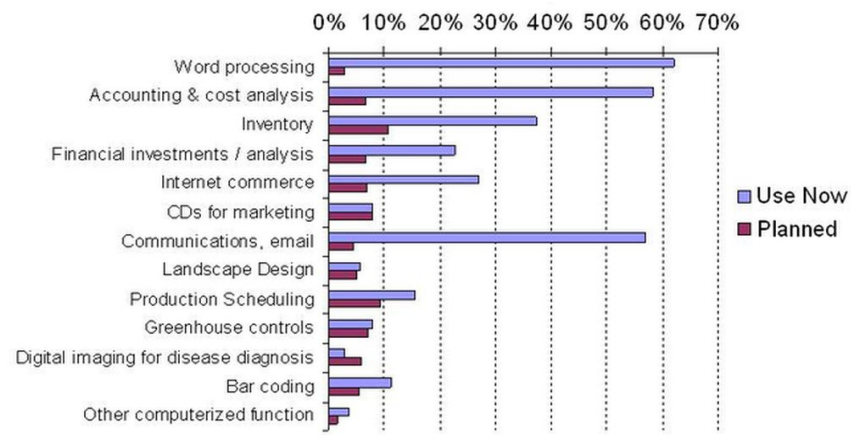

Figure 3. Computer usage by Florida nurseries, 2003.

\section{Nursery Industry Issues}

The nursery and greenhouse industry faces a variety of issues that represent both threats and opportunities that are useful to understand from a public policy standpoint. Survey respondents were asked to rate the importance of a number of issues on a scale of 1 to 4 , with 4 representing "very important" and 1 representing "not important." Results are summarized in Figures 4, 5, and 6. Among the most important factors for price determination were cost of production (3.3), grade of plants (3.1), and market demand (3.0). The high importance of cost of production is consistent with findings in previous surveys. Regarding factors affecting business expansion, the most highly rated factors were production (2.5), personnel (2.4), and marketing (2.4). For general business factors, the most important were market demand (3.2), weather uncertainty (2.7), and competition (2.6).

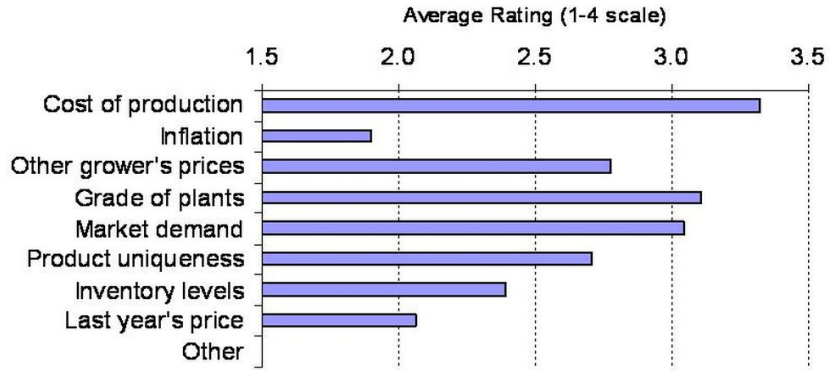

Figure 4. Factors influencing prices for Florida nurseries, 2003.

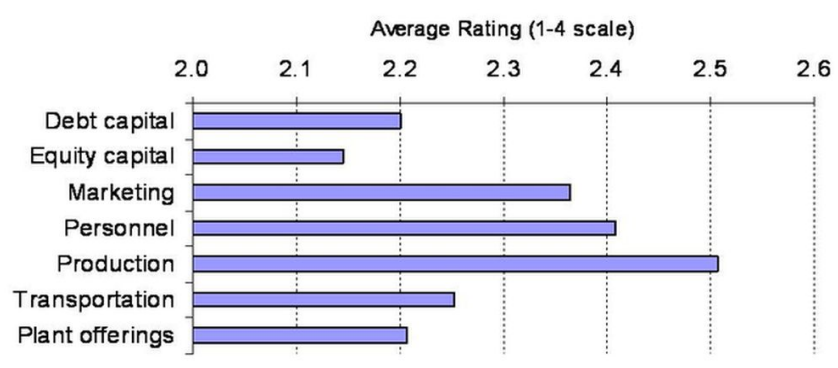

Figure 5. Factors influencing business expansion for Florida nurseries, 2003.

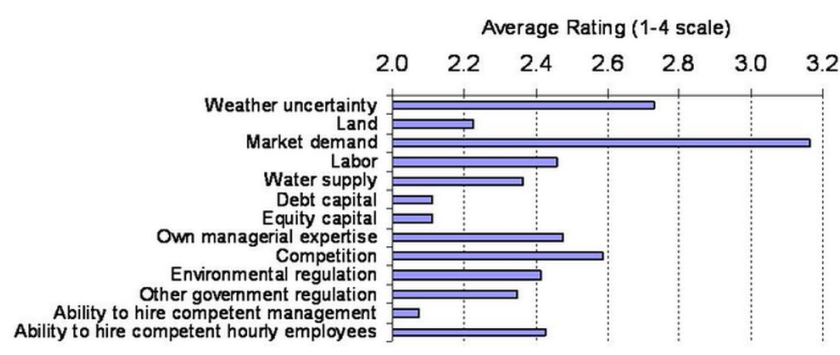

Figure 6. Factors influencing general business for Florida nurseries, 2003.

\section{References}

Brooker, John R., and Steven C. Turner. 1990. Trade Flows and Marketing Practices within the United States Nursery Industry. Southern Cooperative Series Bulletin 358, University of Tennessee Agricultural Experiment Station, Knoxville, TN (October).

Brooker, John R., Steven C. Turner, and Roger A. Hinson. 1995. Trade Flows and Marketing Practices within the United States Nursery Industry: 1993. Southern Cooperative Series Bulletin 384, University of Tennessee Agricultural Experiment Station, Knoxville, TN.

Brooker, John R., Roger A. Hinson, and Steven C. Turner. 2000. Trade Flows and Marketing 
Practices within the United States Nursery Industry: 1998. Southern Cooperative Series Bulletin 397, University of Tennessee Agricultural Experiment Station, Knoxville, TN.

Brooker, John R., David Eastwood, Charles Hall, Kirk Morris, Alan Hodges, and John Haydu. 2005.

Trade Flows and Marketing Practices within the United States Nursery Industry: 2003. Southern Cooperative Series Bulletin 404, University of Tennessee Agricultural Experiment Station, Knoxville, TN.

http://economics.ag.utk.edu/pub/crops/SCB404.pdf.

Hodges, Alan W. and John J. Haydu. 2000. A Decade of Change in Florida's Ornamental Plant Nursery Industry, 1989-99. Economic Information Report EIR-00-3, Food and Resource Economics Department, University of Florida, Gainesville, FL (April).

http://hortbusiness.ifas.ufl.edu/EIR00-3.pdf.

Hodges, Alan W., and John J. Haydu. 2002. Economic Impacts of the Florida Environmental Horticulture Industry, 2000. Economic Information Report EIR-02-3, Food and Resource Economics Department, University of Florida, Gainesville, FL (April).

http://hortbusiness.ifas.ufl.edu/EIR02-3.pdf.

Hodges, Alan W., and John J. Haydu. 1999. Economic Impact of Florida's Environmental Horticulture Industry, 1997. Economic Information Report EIR-99-01, Food and Resource Economics Department, University of Florida, Gainesville (March).

Hodges, Alan W., and John J. Haydu. 1996. The Changing Structure of Florida's Ornamental Plant Nursery Industry, 1989-94. Economic Report ER-96-1, Food and Resource Economics Department, University of Florida, Gainesville, FL.

Jerardo, A. 2005. Floriculture and Nursery Crops Situation and Outlook Yearbook, FLO-2005, Economic Research Service/USDA, Washington, D.C. (June). 
Table 1. Florida nursery firm population, survey sample size and response rate, by size class, 2003.

\begin{tabular}{|lrrrc|}
\hline \hline \multicolumn{1}{c}{ Nursery Size Class } & Population & Firms Sampled & Respondents & Response Rate \\
\hline (Plant Inventory Units) & $($ Number $)$ & $($ Number $)$ & $($ Number $)$ & $($ Percent $)$ \\
Large $(100,000+)$ & 586 & 582 & 151 & $25.9 \%$ \\
Medium $(10,000$ to 99,999) & 1,528 & 907 & 148 & $16.3 \%$ \\
Small (1,000 to 9,999) & 2,419 & 1,365 & 171 & $12.5 \%$ \\
Very Small (less than 1,000) & 3,189 & 0 & 0 & $\mathrm{~N} / \mathrm{A}$ \\
Unknown & & & 6 & $\mathrm{~N} / \mathrm{A}$ \\
Total & 7,722 & 2,854 & 476 & $16.7 \%$ \\
\hline \hline
\end{tabular}

Table 2. Survey sales ranges.

\begin{tabular}{|lr|}
\hline \hline \multicolumn{1}{|c}{ Annual Sales Range } & Midpoint or Average* Value \\
\hline & $(\$ 1,000)$ \\
Less than $\$ 249,999$ & 40.6 \\
$\$ 250,000$ to $\$ 499,999$ & 367.4 \\
$\$ 500,000$ to $\$ 999,999$ & 703.5 \\
$\$ 1,000,000$ to $\$ 1,999,999$ & $1,447.7$ \\
$\$ 2,000,000$ to $\$ 2,999,999$ & $2,388.5$ \\
$\$ 3,000,000$ to $\$ 3,999,999$ & $3,440.0$ \\
$\$ 4,000,000$ to $\$ 4,999,999$ & $4,250.0$ \\
$\$ 5,000,000$ to $\$ 9,999,999$ & $7,425,0$ \\
$\$ 10,000,000$ to $\$ 14,999,999$ & $12,500.0$ \\
$\$ 15,000,000$ to $\$ 19,999,999$ & $17,500.0$ \\
$\$ 20,000,000$ or more & $20,000.0$ \\
\hline${ }^{*}$ Firms reporting actual sales & \\
\hline \hline
\end{tabular}

Table 3. Florida nursery sales reported, by sales range, 2003.

\begin{tabular}{|l|rr|rr|}
\hline \hline \multicolumn{1}{|c|}{ Annual Sales Class } & \multicolumn{2}{|c|}{ Respondents } & $\begin{array}{r}\text { Total Sales } \\
\text { Reported }\end{array}$ & $\begin{array}{r}\text { Share of Total } \\
\text { Sales Reported }\end{array}$ \\
\hline (Range) & (Number) & $($ Percent) & $(\$ 1,000)$ & $($ Percent $)$ \\
Small (less than $\$ 250,000$ & 211 & $44.5 \%$ & 9,292 & $1.5 \%$ \\
Medium (\$250,000 to $\$ 999,999)$ & 124 & $26.2 \%$ & 64,694 & $10.7 \%$ \\
Large (\$1 to $\$ 9.9$ million) & 103 & $21.7 \%$ & 299,842 & $49.7 \%$ \\
Very Large (\$10 million or more) & 12 & $2.5 \%$ & 230,000 & $38.1 \%$ \\
Not Available & 24 & $5.1 \%$ & 0 & $0.0 \%$ \\
Total & 474 & $100 \%$ & 603,828 & $100 \%$ \\
\hline \hline
\end{tabular}


Table 4. Florida nursery employment reported, 2003.

\begin{tabular}{|l|r|r|r|r|}
\hline \hline Employees & \multicolumn{2}{|c|}{ Respondents } & Average Employment Per Firm & Total Employment \\
\hline (Type) & (Number) & $($ Percent $)$ & $($ Number $)$ & $($ Number $)$ \\
Permanent & 407 & $85.5 \%$ & 15.0 & $($ Percent $)$ \\
Temporary & 206 & $43.3 \%$ & 9.4 & $75.9 \%$ \\
Total & 430 & $90.3 \%$ & 104 & 1,935 \\
$24.1 \%$ & $100.0 \%$ \\
\hline \hline
\end{tabular}

Table 5. Product types sold by Florida nurseries, 2003.

\begin{tabular}{|c|c|c|c|c|}
\hline \multirow[t]{2}{*}{ Product } & \multicolumn{2}{|c|}{ Respondents } & \multicolumn{2}{|c|}{ Sales Reported } \\
\hline & (Number) & (Percent) & $(\$ 1,000)$ & (Percent) \\
\hline Other Plants & 122 & $25.7 \%$ & 97,867 & $16.2 \%$ \\
\hline Flowering Potted Plants & 96 & $20.3 \%$ & 77,039 & $12.8 \%$ \\
\hline Foliage & 130 & $27.4 \%$ & 67,463 & $11.2 \%$ \\
\hline Vines \& Ground Covers & 91 & $19.2 \%$ & 47,336 & $7.8 \%$ \\
\hline Bedding Plants (annuals) & 57 & $12.0 \%$ & 45,146 & $7.5 \%$ \\
\hline Propagated Materials & 83 & $17.5 \%$ & 41,691 & $6.9 \%$ \\
\hline Broad-leaved Evergreen Shrubs & 119 & $25.1 \%$ & 37,045 & $6.1 \%$ \\
\hline Evergreen Trees & 112 & $23.6 \%$ & 35,067 & $5.8 \%$ \\
\hline Deciduous Shade \& Flowering Trees & 146 & $30.8 \%$ & 34,872 & $5.8 \%$ \\
\hline Bedding Plants (vegetables, fruits, \& herbs) & 24 & $5.1 \%$ & 31,423 & $5.2 \%$ \\
\hline Fruit Trees & 45 & $9.5 \%$ & 26,104 & $4.3 \%$ \\
\hline Herbaceous Perennials & 59 & $12.4 \%$ & 15,476 & $2.6 \%$ \\
\hline Roses & 30 & $6.3 \%$ & 9,761 & $1.6 \%$ \\
\hline Narrow-leaved Evergreen Shrubs & 68 & $14.3 \%$ & 8,554 & $1.4 \%$ \\
\hline Deciduous Shrubs & 65 & $13.7 \%$ & 8,137 & $1.3 \%$ \\
\hline Azaleas & 67 & $14.1 \%$ & 4,119 & $0.7 \%$ \\
\hline Christmas Trees & 10 & $2.1 \%$ & 325 & $0.1 \%$ \\
\hline Native Plants (not included in product types) & 279 & $58.9 \%$ & 91,351 & $15.1 \%$ \\
\hline
\end{tabular}


Table 6. Media/growing system types used by Florida nurseries, 2003.

\begin{tabular}{|c|c|c|c|c|}
\hline \multirow[t]{2}{*}{ Medium } & \multicolumn{2}{|c|}{ Respondents } & \multicolumn{2}{|c|}{ Sales Reported } \\
\hline & (Number) & (Percent) & $(\$ 1,000)$ & (Percent) \\
\hline Containerized & 397 & $83.8 \%$ & 447,021 & $74.0 \%$ \\
\hline Balled \& Burlapped & 88 & $18.6 \%$ & 58,259 & $9.6 \%$ \\
\hline Other Growing System & 31 & $6.5 \%$ & 55,654 & $9.2 \%$ \\
\hline Bare Root & 58 & $12.2 \%$ & 19,463 & $3.2 \%$ \\
\hline Balled \& Potted & 30 & $6.3 \%$ & 13,801 & $2.3 \%$ \\
\hline In-ground Container (pot-in-pot) & 18 & $3.8 \%$ & 5,948 & $1.0 \%$ \\
\hline Field Grow Bag & 24 & $5.1 \%$ & 3,212 & $0.5 \%$ \\
\hline Process Balled & 4 & $0.8 \%$ & 226 & $0.0 \%$ \\
\hline
\end{tabular}

Table 7. Florida nursery sales by market channel, 2003.

\begin{tabular}{|l|rr|rr|}
\hline \hline Market Channel & \multicolumn{2}{|c|}{ Respondents } & \multicolumn{2}{|c|}{ Sales Reported } \\
\hline & Wumber $)$ & $($ Percent $)$ & $(\$ 1,000)$ & $($ Percent $)$ \\
Retail & 414 & $87.3 \%$ & 547,072 & $90.6 \%$ \\
\hline Re-wholesalers & 179 & $37.8 \%$ & 53,391 & $8.8 \%$ \\
Landscape Firms & 301 & $63.5 \%$ & 186,999 & $31.0 \%$ \\
Retail Garden Centers (single location) & 270 & $57.0 \%$ & 146,218 & $24.2 \%$ \\
Retail Mass Merchandisers & 163 & $34.4 \%$ & 61,839 & $10.2 \%$ \\
Home Improvement Centers & 47 & $9.9 \%$ & 61,036 & $10.1 \%$ \\
Retail Garden Centers (multiple locations) & 49 & $10.3 \%$ & 58,041 & $9.6 \%$ \\
\hline Brokered for Other Growers & 86 & $18.1 \%$ & 25,323 & $4.2 \%$ \\
Contracted Production & 223 & $47.0 \%$ & 101,394 & $16.8 \%$ \\
\hline \hline
\end{tabular}

Table 8. Sales methods used by Florida nurseries, 2003.

\begin{tabular}{|l|rr|rr|}
\hline \hline Method & \multicolumn{2}{|c|}{ Respondents } & \multicolumn{2}{|c|}{ Sales Reported } \\
\hline & $($ Number $)$ & $($ Percent $)$ & $(\$ 1,000)$ & $($ Percent $)$ \\
Telephone & 344 & $72.6 \%$ & 314,790 & $52.1 \%$ \\
In-person & 397 & $83.8 \%$ & 204,737 & $33.9 \%$ \\
Trade Shows & 100 & $21.1 \%$ & 24,706 & $4.1 \%$ \\
Mail Order & 33 & $7.0 \%$ & 14,780 & $2.4 \%$ \\
Internet & 61 & $12.9 \%$ & 4,987 & $0.8 \%$ \\
\hline \hline
\end{tabular}


Table 9. Florida nursery advertising expenses, 2003.

\begin{tabular}{|l|rr|rr|}
\hline \hline Advertising & \multicolumn{2}{|c|}{ Respondents } & \multicolumn{2}{|c|}{ Expenses Reported } \\
\hline (Type) & (Number) & $($ Percent $)$ & $(\$ 1,000)$ & $($ Percent $)$ \\
Trade Shows & 123 & $25.9 \%$ & 6,078 & $51.4 \%$ \\
Trade Journals & 115 & $24.3 \%$ & 1,723 & $14.6 \%$ \\
Other Types Advertising & 70 & $14.8 \%$ & 876 & $7.4 \%$ \\
Gardening Publications & 37 & $7.8 \%$ & 614 & $5.2 \%$ \\
Catalogs & 65 & $13.7 \%$ & 602 & $5.1 \%$ \\
Yellow Pages & 65 & $13.7 \%$ & 410 & $3.5 \%$ \\
Web Sites & 85 & $17.9 \%$ & 387 & $3.3 \%$ \\
Newsletters & 44 & $9.3 \%$ & 217 & $1.8 \%$ \\
Radio/TV & 10 & $2.1 \%$ & 120 & $1.0 \%$ \\
Billboards & 6 & $1.3 \%$ & 7 & $0.1 \%$ \\
\hline Total Advertising Expenses & 278 & $58.6 \%$ & 11,836 & \\
\hline \hline
\end{tabular}

Table 10. Florida nursery sales to specific states, 2003.

\begin{tabular}{|c|c|c|c|c|c|}
\hline \multirow[t]{2}{*}{ Destination State } & \multicolumn{2}{|c|}{ Total Sales Reported } & \multirow[t]{2}{*}{ Destination State } & \multicolumn{2}{|c|}{ Total Sales Reported } \\
\hline & $(\$ 1,000)$ & (Percent) & & $(\$ 1,000)$ & (Percent) \\
\hline Florida & 352,761 & $70.7 \%$ & Wisconsin & 1,416 & $0.3 \%$ \\
\hline Georgia & 28,330 & $5.7 \%$ & Minnesota & 921 & $0.2 \%$ \\
\hline Alabama & 19,547 & $3.9 \%$ & Kentucky & 837 & $0.2 \%$ \\
\hline South Carolina & 18,765 & $3.8 \%$ & Maryland & 821 & $0.2 \%$ \\
\hline Texas & 12,147 & $2.4 \%$ & Nevada & 793 & $0.2 \%$ \\
\hline California & 10,880 & $2.2 \%$ & Arkansas & 702 & $0.1 \%$ \\
\hline North Carolina & 8,520 & $1.7 \%$ & Arizona & 592 & $0.1 \%$ \\
\hline New York & 8,244 & $1.7 \%$ & Indiana & 488 & $0.1 \%$ \\
\hline Michigan & 5,493 & $1.1 \%$ & Connecticut & 422 & $0.1 \%$ \\
\hline Illinois & 3,379 & $0.7 \%$ & Colorado & 380 & $0.1 \%$ \\
\hline Ohio & 3,311 & $0.7 \%$ & Oklahoma & 358 & $0.1 \%$ \\
\hline Pennsylvania & 3,159 & $0.6 \%$ & Missouri & 331 & $0.1 \%$ \\
\hline New Jersey & 2,721 & $0.5 \%$ & Hawaii & 156 & $<0.1 \%$ \\
\hline Louisiana & 2,705 & $0.5 \%$ & Massachusetts & 156 & $<0.1 \%$ \\
\hline Mississippi & 1,792 & $0.4 \%$ & lowa & 72 & $<0.1 \%$ \\
\hline Tennessee & 1,688 & $0.3 \%$ & West Virginia & 72 & $<0.1 \%$ \\
\hline Virginia & 1,471 & $0.3 \%$ & & & \\
\hline
\end{tabular}


Table 11. Florida nursery sales to specific countries or regions, 2003.

\begin{tabular}{lrr|}
\hline \hline Destination Country/Region & \multicolumn{2}{c|}{ Total Value Reported } \\
\hline & $(\$ 1,000)$ & $($ Percent $)$ \\
Canada & 2,376 & $0.5 \%$ \\
Holland & 1,011 & $0.2 \%$ \\
Carribean Basin & 819 & $0.2 \%$ \\
Bahamas & 503 & $0.1 \%$ \\
Spain & 434 & $0.1 \%$ \\
Belgium & 358 & $0.1 \%$ \\
Australia & 149 & $<0.1 \%$ \\
South America & 24 & $<0.1 \%$ \\
Puerto Rico & 15 & $<0.1 \%$ \\
Central America & 2 & $<0.1 \%$ \\
Costa Rica & 2 & $<0.1 \%$ \\
Germany & 2 & $<0.1 \%$ \\
St. Croix & 2 & $<0.1 \%$ \\
St. Thomas & 2 & $<0.1 \%$ \\
\hline \hline
\end{tabular}

Table 12. Water sources and irrigataion methods used by Florida nurseries, 2003.

\begin{tabular}{|c|c|c|c|}
\hline Irrigation Water Source Used & $\begin{array}{l}\text { Share of Average } \\
\text { Total Water Used }\end{array}$ & Irrigation Method Used & Respondents Using \\
\hline (Type) & (Percent) & (Type) & (Percent) \\
\hline Wells & $77 \%$ & Overhead & $76 \%$ \\
\hline Natural Surface & $14 \%$ & Drip & $48 \%$ \\
\hline Recaptured & $3 \%$ & $\begin{array}{l}\text { Subirrigataion, } \\
\text { ebb-flood }\end{array}$ & $5 \%$ \\
\hline Municipal & $5 \%$ & Other & $10 \%$ \\
\hline
\end{tabular}


Appendix. Survey Questionnaire

1. From what state are you reporting?

What is your ZIP code?

Does your business operate a nursery in another state? (yes / no)

If yes, please list the state(s)

2. In what year was your firm established?

3. How many people does your firm employ at this location?

Permanent employees

Temporary employees (average number during your peak season)

Has the number of employees over the last five years increased, stayed the same, decreased?

Permanent

Temporary

If employment has changed, indicate by what percent?

4. What functions of your firm are computerized now, and which ones are planned within the next five years?

Word processing

Accounting / cost analysis

Inventory

Financial investments / analysis

Internet commerce (B2B or B2C)

CDs for marketing

Communications - E-mail

Landscape designing (CAD)

Production scheduling

Greenhouse production controls

Digital imaging for disease diagnosis

Bar coding

Other (please list)

5. What percentage of your sales are in the following plant categories?

Deciduous shade and flowering trees

Deciduous shrubs

Broad-leaved evergreen shrubs (excluding Azaleas)

Narrow-leaved evergreen shrubs

Evergreen trees

Azaleas

Vines and grounds covers

Roses

Herbaceous perennials

Bedding plants - flowering annuals

Bedding plants - vegetables, fruits, and herbs

Flowering potted plants

Christmas trees (live or cut)

Tree fruits

Foliage

Propagated material (liners, cuttings, plugs, etc.)

Other 
Appendix. Survey Questionnaire

6. What is your firms source of irrigation water?

Natural surface

Recaptured

City

Well

7. Has your use of irrigation water on a per acre basis changed over the past five years? Has it increased, remained the same, or decreased. If irrigation water has changed, indicate by what percent?

8. What irrigation methods do you use?

Overhead

Drip

Subirrigation (Ebb / flood)

Other

9. Please place a check mark beside each of the following IPM activities that you practice.

Remove infested plants or plant parts

Alternate pesticides to avoid chemical resistance

Elevate or space plants for air circulation

Use cultivation, hand weeding

Disinfect benches/ground cover

Use sanitized water foot baths

Soil solarization/sterilization

Monitor pest populations with tarp or sticky boards

Adjust pesticide application to protect beneficials

Use mulches to suppress weeds

Beneficial insect identification

Inspect incoming stock

Manage irrigation to reduce pests

Spot treatment with pesticides

Ventilate greenhouses

Use of beneficial insects

Keep pest activity records

Adjust fertilization rates

Use screening/barriers to exclude pests

Use biopesticides/lower toxicity

Treat retention pond water

Use pest resistant varieties

10. What percentage of your sales are in the following forms?

\section{Bare root}

Balled and potted

Balled and burlapped

Processed balled

Container

Field grow bag

In-ground containers (pot-in-pot)

Other (please list, e.g., cut Christmas trees)

11. What are the top five states (or countries), including your own state, from which you purchase seedlings, liners, whips, grafted material, tissue culture plantlets, cuttings, or plugs? 
Appendix. Survey Questionnaire

12. What percent of total sales is from native plants? Native plants are defined as those present in your state before European settlement.

13. At how many trade shows was your firm represented in 2003 ? With an exhibit / Without an exhibit.

14. What percentage of your sales are to repeat customers?

15. Do you publish discount (price) information for large-volume purchases? (yes / no)

16. What percent of your sales are negotiated sales? (Negotiated means there was discussion/debate over price, quality or other terms of sale)

17. What percentage of your sales transactions are made using the following methods

Trade show orders

Telephone orders

In-person orders

Mail orders

Internet sales

18. What percent of your 2003 total annual sales were Wholesale or Retail?

19. If you sell wholesale, what percentage of your wholesale sales (from question 18) are to:

Mass merchandisers (general merchandise stores, supermarkets, etc.)

Home Centers (home improvement, building supply outlets, hardware, etc.)

Garden centers (single location)

Garden Centers (multiple locations)

Landscape firms (in-house or external)

Re-wholesalers (brokers, other growers, etc.)

20. Do you export nursery products out of the U.S.? (yes / no)

If yes, what percentage of total sales are from exports?

If you export, please list the countries:

21. What are the top five states (or countries), including your own state, that are destinations for your firm's total sales?

22. Do you handle/resell items from other growers? (yes / no)

If yes, what percent of your total sales does this account for?

23. What percentage of your total sales are on contract, in other words, sold or committed before being planted/potted?

24. What types of buyer(s) are contracting for production with your firm?

Other producers

Retail garden centers

Mass merchandisers

Cooperatives

Other (please specify) 
Appendix. Survey Questionnaire

25. Regarding price determination, please rate the level of importance of each factor by using the 1 to 4 scale, with $1=$ not important; $2=$ minor importance; $3=$ important; and $4=$ very important.

Cost of production

Inflation

Other growers' prices

Grade of plants

Market demand

Product uniqueness

Inventory levels

Last year's price

Other (please specify)

26. Regarding factors that might limit the expansion of the geographic scope of your trading area, please rate the level of importance of each factor by using the 1 to 4 scale, with $1=$ not important; $2=$ minor importance; $3=$ important; and $4=$ very important.

Debt capital

Equity capital

Marketing

Personnel

Production

Transportation

Plant offering

27. Please rate each of the factors listed below according to how much they impact your business by using the

1 to 4 scale, with $1=$ not important; $2=$ minor importance; $3=$ important; and $4=$ very important.

Weather uncertainty

Land

Market demand

Labor

Water supply

Debt capital

Equity capital

Own managerial expertise

Competition / Price undercutting

Environmental regulations

Other government regulations

Ability to hire competent management

Ability to hire competent hourly employees

28. What percentage of total sales did your firm spend on advertising in 2003?

How do you allocate these advertising dollars?

Web sites

Yellow pages

Radio / TV

Billboards

Gardening publications

Catalogs (print or CD)

Trade journals

Newsletters

Trade shows

Other (please specify) 
Appendix. Survey Questionnaire

29. What was the gross value of product sales from your nursery in 2003 , or your most recently completed fiscal year? Please check the appropriate category below, or enter the value here $\$$

Less than $\$ 249,999$

$\$ 250,000-\$ 499,999$

$\$ 500,000-\$ 999,999$

$\$ 1,000,000-\$ 1,999,999$

$\$ 2,000.000-\$ 2,999,999$

$\$ 3,000,000-\$ 3,999,999$

$\$ 4,000,000-\$ 4,999,999$

$\$ 5,000,000$ - $\$ 9,999,999$

$\$ 10,000,000$ - \$14,999,999

$\$ 15,000,000$ - $\$ 19,999,999$

$\$ 20,000,000$ or above 